\title{
Study on the Effectiveness of Internal Control of Enterprises Listed on SMEs Board
}

\author{
Juan ZHANG \\ Wuhan Business University, Wuhan, 430056, China \\ E-mail: 476251135@qq.com
}

\begin{abstract}
Key words: Enterprises Listed on SMEs Board; Internal Control; The Effectiveness of Internal Control
\end{abstract}

\begin{abstract}
The rapid development of market economy has brought about the more fierce competition among enterprises. Under such circumstances, only through effectively improving the core competition of one's own enterprises can a favorable position in the market be obtained. For the fact that internal control is the core of enterprise management, we must to a large extent establish a sound enterprise internal control system. Specificity speaking, the system should to be standardized to meet the requirements of social market, so that we can more efficiently acquire economic benefits and moreover, promote national economic development. This paper chose enterprises listed on SMEs board as the object of study, since most of SMEs grow up from private enterprises faced with many risks and challenges. As an effective way to avoid the enterprise risk, corporate governance and internal control are highly regarded by the regulators and managements. In this paper, the author first analyzes the characteristics of enterprises listed on SMEs board, then completely and systematically expounds the theoretical concepts involved in this paper such as the internal control and the effectiveness of internal control. And finally the evaluation criteria of the effectiveness of internal control are put forward.
\end{abstract}

\section{Introduction}

Since the establishment of SMEs board, many enterprises have made remarkable achievement. Within merely two years, the total number of listed companies has reached 100. [1] Furthermore, the overall business performance of enterprises listed on SMEs board is significantly better than the main board, which has shown an obvious "three High", features: high share price, high price-earnings ratio and high turnover rate. Currently, the SMEs board has shown its strong competitive strength in attracting funds and high-quality listing of resources. In the meantime, we also observe that private enterprises are dominant in SMEs board. Also the reality of "one shareholder overwhelms the others" is inevitable, and the phenomenon of family control is more common nowadays. [2] Therefore, Chairman of the board with absolute control is more prominent among enterprises,

By this ownership structure, the separation of proprietary rights from management rights in private listed companies is not distinct enough, and there are members of the board of director's act as (deputy) general manager or other senior positions in most companies. [3] This has a negative impact on the internal control and risk management of enterprises listed on SMEs board. As a consequence, both the decision-making mechanism and the restraint mechanism of enterprises need to be perfected.

\section{Sample analysis of enterprises listed on SMEs board}

\section{A. regional distribution}

Compared with the listed companies on the main board, enterprises listed on SMEs board have more distinct regional features. In the sample analysis, the top 5 provinces listed on SMEs board are Guangdong (72), Zhejiang (50), Jiangsu (32), Shandong (23) and Anhui (14), accounting for $64.26 \%$ of the total sample. 


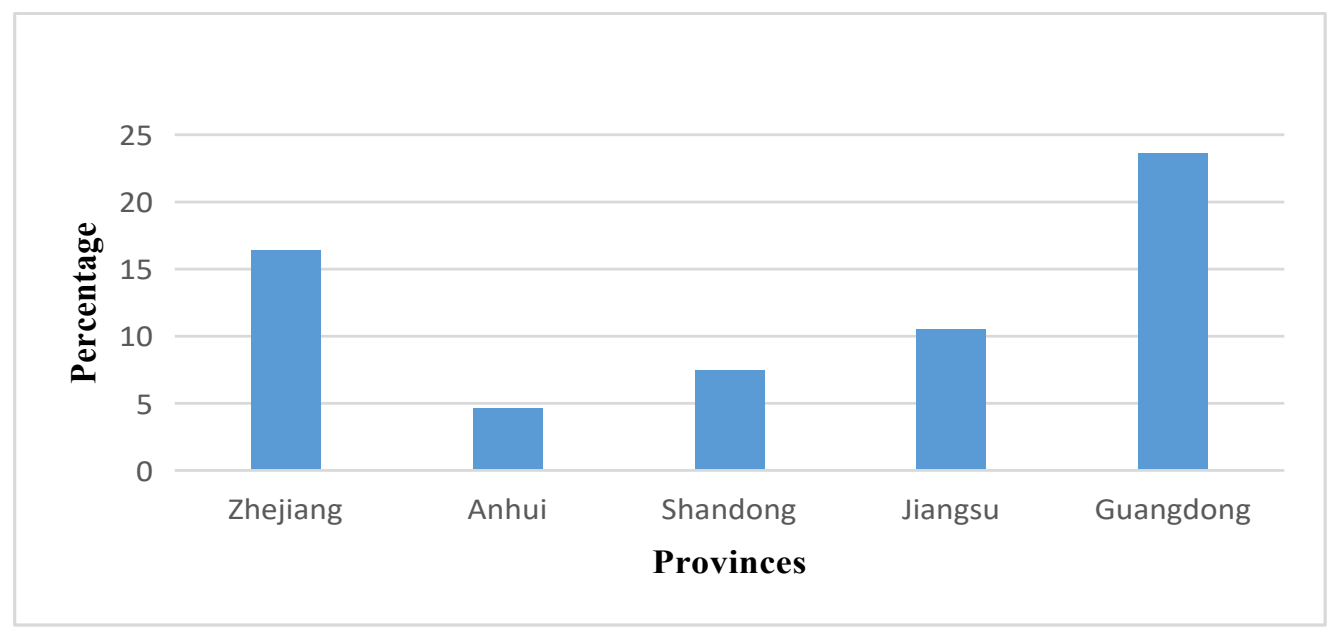

Figure 1: Quantity ratio of SMEs enterprises in different provinces

\section{B. Industrial distribution}

Among the 305 enterprises listed on SMEs board in the sample, they are mainly in the chemical industry, electrical equipment, electronic components, mechanical equipment, pharmaceutical biotechnology, light manufacturing, building materials, information services and textile and garment industries, with a total amount of 211 , accounting for $69.18 \%$.

\section{The concept of internal control of enterprises listed on SMEs board}

\section{A. The concept of internal control}

From the perspective of contemporary management science, "control" means to operate, to manage, to command, or to regulate. [4] [5]It seems that any organizations would like to operate in an orderly and efficient way. Hence they need some control to minimize decision-making mistakes and drawbacks in the work, for example, to provide reliable financial accounting information and management information for different needs. When such control is implemented within an organization, namely internal control, internal control, refers to the intro-implementation of various constraints and regulations in organization in order to improve the efficiency, make full use of resources and to achieve the established management objectives. In effect, it is a kind of management control and an essential tool to effectively carry out the strategies of organization.

\section{B. Definition of the effectiveness of internal control}

The effectiveness of internal control is a comprehensive evaluation process to provide more than a reasonable level with the objectives relevant to internal control. [6] This kind of effectiveness is measured in a reasonable range, if it falls within a reasonable range, then the internal control is effective; otherwise, it is ineffective. An effective internal control depends on two aspects: one is the design effectiveness and the other is operational effectiveness. The effectiveness of the internal control can take COSO report (five elements of internal control in 1992 and eight elements of the overall ERM framework in 2004) as criteria. However, the effectiveness of internal control should be determined by some evaluation methods from the aspects of its objectives and elements.

\section{Existing problems in internal control of enterprises listed on SMEs board}

At present, the government has its control of listed companies. For example, it has strengthened the awareness of internal control and improved the internal control system. Nevertheless, there are still problems as follows:

\section{A. Internal control environment of enterprise is weak}

On the one hand, many enterprises listed on SMEs board emphasize more on production and operation rather than internal control, and consciousness of internal control is not raised. On the other hand, largest shareholders in enterprises listed on SMEs board take the important post and 
they grasp the actual control of management, and there are few professional managers responsible for the management. Therefore, the internal control environment of enterprise is weak because it does not scientific enough for business performance.

\section{$B$. The internal control system is not sound enough}

The internal control system of many enterprises is not sound enough, because it is not specific to all departments and staff, the departments of enterprise has no effective mutual supervision and restraint. [7]Although the internal control system in enterprises and companies have been established, but its initiative still needs to be strengthened. Especially in most cases, they merely aim to meet the inspection and requirement rather than actually improve its internal control system. If the supervision and management departments do not carry out their own supervision capability, the enterprises and companies will not improve the relevant internal control system. To sum up, enterprises listed on SMEs board do not bring about positive effects to the establishment and perfection of internal control system.

\section{Degree of standardization within the internal control system of enterprises listed on SMEs} board is not enough

The standard system of internal control of enterprises listed on SMEs board should include: internal control application guidelines, the basic norms of internal control, internal control guidelines, internal control evaluation guidelines. However, most of the internal control system nowadays is not sound enough. [8] From the reports of self-evaluation on enterprises' internal control, outwardly the system has some effect, but in fact, the results of these self-evaluation can not conceal the real situation within companies, and there exist irregularities in most of the companies.

D. The self-evaluation on internal control of enterprises listed on SMEs board remains to be refined

Due to the requirements of supervision and management departments, enterprises listed on SMEs board must do a self-evaluation on the effect of their internal control and report to the relative departments. However, from the material submitted, we can find the report is devoid of content without any value. [9]The report is just to meet the requirements of the regulatory authorities. Therefore, the content of self-evaluation must be refined, like the basis of internal control, the scope of implementation, the methods and procedures. The simple self-evaluation report can only bring a false impression, so that the internal control becomes disordered and influences on the economic efficiency of enterprises.

\section{Evaluation of the effectiveness of internal control of enterprises listed on SMEs board}

The general standard of internal control evaluation is the goal of the internal control system, which includes three goals, the evaluation of the effectiveness of internal control, evaluation of internal control rationality and of the integrity of internal control.

Table 1: Internal control standard of enterprises listed on SMEs board 


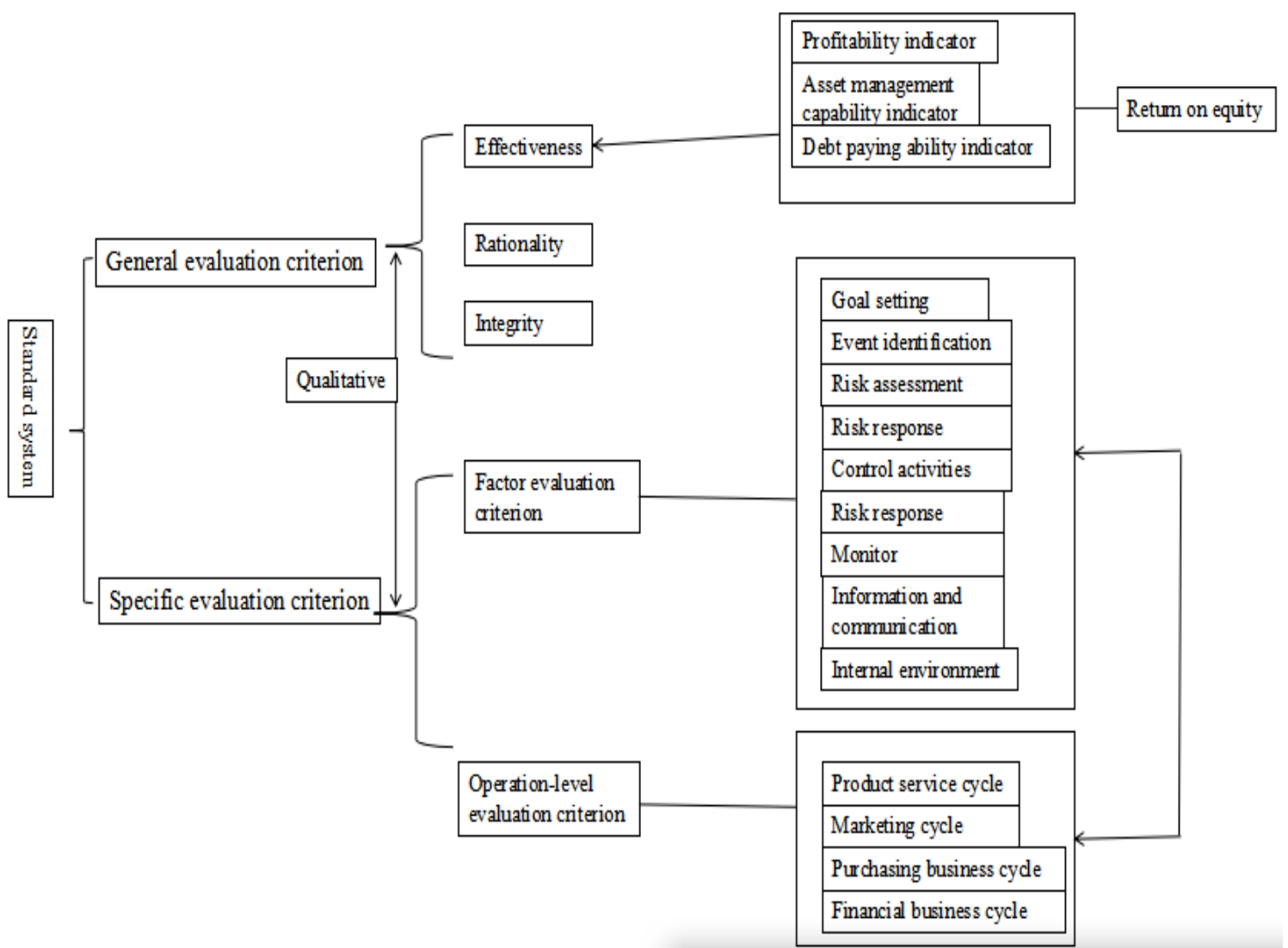

Each of the goals includes two meanings. Specifically speaking, integrity for one thing means all the internal control should be set to meet the production and operation needs; for another, it means that these controls should be implemented from the beginning to the end. Rationality for one thing refers to the applicability of the design and implementation of internal controls; and for another, it refers to the effectiveness of the design and implementation of internal controls. Effectiveness for one thing means that the internal policies and measures are not in violation of the relevant laws and regulations of the state; for another, it means the design of complete and reasonable internal control in the production and operation process has been implemented and plays its role.

In addition to the general standards for internal control evaluation, there are specific standards, which refer to the standards applied to the specific parts of internal control evaluation. These two standards are closely related, the general standard is the guidance of specific one, and the specific standard is a measure of the general one. The existing specific standard of internal control is divided into element evaluation criterion and operation-level evaluation criterion, which are blend with each other as well. Therefore, in the process of evaluation of the effectiveness of internal control, appropriate evaluation should be based on the concrete conditions.

\section{Conclusion}

Since the reform and opening up, enterprises, listed on SMEs board in social market economy, is booming. Owing to the limitation of private enterprises and enterprises listed on SMEs board, the internal control problems become more and more prominent. With a limited time for development, the SMEs enterprises nowadays still emphasize on its profitability and corporate governance and neglect the study of internal control, so there is a gap in research of the application of internal control in SMEs enterprises. In this paper, the internal control of enterprises listed on SMEs board is studied on the basis of the development background, significance, analysis of the status of development, and finally the relevant recommendations. This paper aims to enhance the competitiveness of the SMEs enterprises and to bring us more economic efficiency. 


\section{References}

[1] Masaji Kano,Hirofumi Uchida,Gregory F. Udell,Wako Watanabe. Information verifiability, bank organization, bank competition and bank-borrower relationships[J]. Journal of Banking and Finance . 2010 (4)

[2] Morck R,Shleifer A,Vishny R.Management Ownership and Market Valuation: An Empirical Analysis. The Journal of Finance. 1988

[3] Robert E. Carpenter,Alessandra Guariglia. Cash flow, investment, and investment opportunities: New tests using UK panel data [J]. Journal of Banking and Finance. 2007 (9)

[4] Bhojraj,S,P Sengupta.Effect of Corporate Governance on Bond Ratings and Yields:The Role of Institutional Investors and the Outside Directors. Journal of Business. 2003

[5]Fama,Eugene F.Agency Problem and the Theory of the Firm. Journal of Politics. 1980

[6] Jayanthi Krishnan.Audit committee Quality and Internal Control an Empirical Analysis. The Accounting Review . 2005

[7] Joseph P.H. Fan,T.J. Wong,Tianyu Zhang. Politically connected CEOs, corporate governance, and Post-IPO performance of China's newly partially privatized firms[J]. Journal of Financial Economics . 2007 (2)

[8] Hongbin Li,Lingsheng Meng,Qian Wang,Li-An Zhou. Political connections, financing and firm performance: Evidence from Chinese private firms [J].Journal of Development Economics.2007 (2)

[9] Udi Hoitash,Rani Hoitash,Jean C Bedard.Corporate Governance and Internal Control over Financial Reporting:A Comparison of Regulatory Regimes. The Accounting Review. 2009 